\title{
The Implementation of Prudential Banking Principles to Prevent Debtor with Bad Faith
}

\author{
Etty Mulyati* \\ DOI: https://doi.org/10.22304/pjih.v5n1.a5
}

Submitted: January 30, 2018 | Accepted: April 23, 2018

\begin{abstract}
Bank credit channeling is not entirely returned at the maturity of credit. This phenomenon causes bad debts. The occurrence of bad debts, among others, comes from debtors who do not have good faith. Many debtors, deliberately with all efforts, try to get credits. However, after they obtain the credits, they use the credits for the interests that cannot be accounted. In some cases, debtors even ran away before the maturity of credit. This raises the issue of how banks apply the precautionary principle of dealing with unqualified debtors, the debtors with bad faiths. To anticipate bad-faith debtors, it is mandatory for banks to apply the precautionary principles, known as the $5 \mathrm{C}$ principles and to apply risk management in order to avoid bad debts before credit agreement is approved. After credits are channeled, banks routinely supervise the development of credits to avoid deviations from the terms of agreement. In the event of bad debt, and bank solved it by executing the object of guarantee, the availability of material security is one of the factors that determines the properness of credit channeling. It should be performed with the binding of a formal juridical guarantee based on the legislations on guarantees.
\end{abstract}

Keywords: bad faith, credit agreement, prudential principles.

\section{Penerapan Prinsip Kehati-Hatian Bank Terkait Debitur Beritikad Tidak Baik}

\begin{abstract}
Abstrak
Penyaluran kredit perbankan tidak seluruhnya dapat dikembalikan sesuai waktu yang telah diperjanjikan, hal ini dapat mengakibatkan kredit macet. Terjadinya kredit macet antara lain berasal dari debitur yang beritikad tidak baik, debitur sengaja dengan segala daya upaya mendapatkan kredit tetapi setelah diperolehnya, menggunakan kredit untuk kepentingan yang tidak dapat dipertanggungjawabkan bahkan debitur sudah melarikan diri sebelum jatuh tempo kreditnya. Hal tersebut menimbulkan permasalahan bagaimana bank menerapkan prinsip kehati-hatian menghadapi debitur beritikad tidak baik. Bank mengantisipasi debitur beritikad tidak baik, sebelum perjanjian kredit disetujui, diwajibkan menerapkan prinsip kehati-hatian berdasarkan prinsip 5C dan menerapkan manajemen risiko agar terhindar dari kredit macet. Setelah kredit disalurkan bank secara rutin mengawasi perkembangan kreditnya agar tidak terjadi penyimpangan dari ketentuan perjanjian kredit. Jika terjadi kredit macet penyelesaiannya dengan mengeksekusi objek jaminan, dengan demikian ketersediaan jaminan kebendaan merupakan salah satu faktor dalam menentukan layak tidaknya kredit dikucurkan, dengan pengikatan jaminan yang secara yuridis formal sesuai dengan peraturan perundang-undangan tentang jaminan.
\end{abstract}

PADJADJARAN Journal of Law Volume 5 Number 1 Year 2018 [ISSN 2460-1543] [e-ISSN 2442-9325]

Lecturer at Faculty of Law, Universitas Padjadjaran, J. Dipati Ukur No. 35, Bandung, etmul21@gmail.com, S.H., M.H. Dr. (Universitas Padjadjaran) 
Kata kunci: itikad tidak baik, perjanjian kredit, prinsip kehati-hatian.

\section{A. Introduction}

Prudential banking principles must be implemented by banks in conducting their business activities. It is very important since, in carrying out their business activities, banks manage third party funds that the people entrust. Prudential banking principles means that a bank, in making policies and running its business activities, must always comply with all effective laws and regulations based on good faith. Prudential banking principles is an implementation of bank responsibilities to depositors. Thus, bank must maintain the level of health and maintain public trust since trust is the main keyword for the development of a bank.

Bank is a financial institution that plays strategic role and position in national development. Banking can be viewed as the soul of a country's economy. If the world of banking is destroyed, the economy will be destroyed. Bank has become essential to the economic life of every modern society. A successful banking system has not only become the crucial for the functioning of every business, it has become the central routine of most people. ${ }^{1}$ Progress of a bank in a country can also be used as a measure of the country's progress. The more advanced a country, the greater the role of bank in controlling the country. The existence of banking world is increasingly needed by government and society. ${ }^{2}$

The main function of bank is to collect and distribute public funds. Based on the function, bank is called intermediary institution. Bank collects public funds in the form of savings, time deposits, certificates of deposit, demand deposits, and others. Then channel funds to the community, among others in the form of credit. Bank as an intermediary institution, which is to bridge the parties with funds (creditor) and parties without funds (debtors), aims to improve living standard of many people. As an intermediary institution, bank must be able to perform its functions properly and maximally because bank is a financial institution that becomes a place for individuals, private business entities, state-owned enterprises, and even government institutions to save funds. Through the saving activities, the channeling of funds and various services are provided by bank. Bank serves customer's needs and launches payment system mechanism for all sectors of economy.

In Indonesia, in addition to the general functions, bank also has a special function as an agent of development. Bank is an institution that supports the implementation of development and its results, economic growth, and national stability towards people's life improvement. ${ }^{3}$ As mentioned in Article 4 of Law Number 7 of 1992 on the Amendment of Law Number 10 of 1998 on the Banking (Banking Law):
"Perbankan Indonesia bertujuan menunjang pelaksanaan pembangunan nasional dalam rangka meningkatkan pemerataan,

Andreas Busch, Banking Regulation and Globalization, New York: Oxford University Press, 2009, p. 23. Kasmir, Dasar-dasar Perbankan, Jakarta: Raja Grafindo Persada, 2002, p.1.

Muhamad Djumhana, Hukum Perbankan di Indonesia, Bandung: PT. Citra Aditya Bakti, 2000, p. 86. 


\section{pertumbuhan ekonomi dan stabilitas nasional ke arah peningkatan kesejahteraan rakyat banyak". \\ [Indonesian banking aims to support the implementation of national development to improve equity, economic growth, and national stability towards the improvement of people's welfare]}

This is in accordance with the objectives of Indonesian banking system that banking financial institutions have a strategic role in supporting the implementation of national development, especially in economic activities; and must benefit people's welfare.

Bank distribute funds to communities that require funds for both working capital and for investment, among others, through credit. Credit is one of bank's business activities that has a very important role in economic development, in addition to providing goods and services in the field of payment traffic and money circulation. Credit enables business actors to increase production, to expand business development, and to increase weak businesses. Increased business means an increase in profits, thus revenues will increase and corporate taxes will increase. Increased business and establishment of new projects require many workers. It will affect people's income that will eventually make equity and welfare of people. Credit channeling play a major role in implementation of development program. Credit provides various possibilities in economic traffic, especially in the sectors of rural development, urban development, trading, transportation, and business.

For bank, credit is to seek profit; and is an effort to obtain results in the form of interest received by the bank as turnover. Credit provision is charged to debtor, in the hope that debtors who obtain credit can develop and expand business. The more credit is channeled, the more entrepreneurs can develop. The progress of debtor's business means to gain profit, this is important for the survival of banks and debtors.

Credit channeling means that bank gives confidence to debtor after a thorough analysis of good faith and debtor's ability to repay debt in accordance with time specified in credit agreement. Bank is a lender in providing trust fund loans, so that the person or legal entity who obtained credit have gained trust from bank. Bank confidence in debtors has a high risk. Debtor, sometimes, cannot return credit channeling, on the maturity. This can lead to bad credit.

Bad credit is one of the risks faced by the bank in its credit business. Credit risk is a level of risk that is faced as a result of a period of time that separates between awarding credit and default to be accepted in the future. The longer the term credit is given, the higher level of risk for bank. Despite the ability of human being to break through the future, there is always an element of uncertainty that cannot be taken into account. ${ }^{4}$ Credit risk represents the risk of loss suffered by bank. It is in relation to the likelihood that at the maturity, debtor fails to fulfill obligations to bank. 
The presence of nonperforming loans and bad debts can have a negative effect on bank, reducing the bank's soundness, disrupting bank operations and reducing bank assets. If not immediately handled seriously, bad debts in large numbers can shake national economy, which then lead to economic crisis. Credit creation is the prime operation of the banks, but, it exposes to credit risk for the bank due to the failure of the borrowers to fulfill the commitment with the banks. Moreover, banks need identify and manage the credit risk prudently because it may affect profitability and lead a bank to the banking crisis and economy to systematic crisis. ${ }^{5}$

In addition to problems arising from bank, the occurrence of bad debts in credit agreements also comes from debtors. There are several factors that influence the occurrence of non-performing loans from bank. They are, among others, lack of accuracy in analyzing creditworthiness of debtors, supervision of credit information system, use of credit, development of debtor's business activities, and smooth communication between debtor and the bank. The external factors include development of economic conditions such as monetary crisis or decrease in sale of goods and services that debtor seeks. Natural factors will affect the occurrence of non-performing loans, namely the existence of natural disasters that bring about decline in business debtors, but debtors with bad faith, both large and small debtors, mostly cause bad credit that occurred in Indonesian banking industry.

Debtors with bad faith make credit loans to dredge profits as much as possible for their own interests. These debtors deliberately get credit with all efforts but after that, they use the credit for interests that cannot be accounted. In some cases, the debtors even have already run away before the maturity of credit. This raises the issue of how banks apply prudential principles to formation and implementation of credit agreements against unqualified debtors, in order to prevent the occurrence of bad debts.

\section{B. Principles of Good Faith in Agreement}

Credit agreement is an agreement between bank and debtor to grant a loan from the bank to the debtor. Credit agreement usually contains rights and obligations of each party, which will become law for the involving parties. This principle establishes a contractual relationship and places rights and obligations to the parties in accordance with the agreement that is mutually agreed.

An agreement is an event in which a person promises another person to promise to do one thing. Agreement, under Article 1313 of the Indonesian Code of Civil Law (Civil Code), is:

"Suatu perjanjian adalah suatu perbuatan dengan mana satu orang atau lebih mengikatkan dirinya terhadap satu orang".

Abu Hanifa Md. Noman, "The Effect of Credit Risk on the Banking Profitability: A Caseon Bangladesh", Global Journal of Management and Business Research (C) Finance, Vol. 15, Issue 3, 2015, p. 46. 
[An agreement is an act by which one or more persons commit themselves to another person]

There is a comment on the definition that this definition is incomplete and too broad. It should be: "An agreement is a legal act by which one or more persons bind themselves to another person".

From the event, there is a legal relationship between two or more persons called an engagement. In other words, an agreement issues an engagement. Law does not provide the definition of engagement. Even though the Book III of the Civil Code is entitled Perikatan [engagement], not a single article provides an understanding of an engagement. Therefore, based on the Civil Law, engagement is a legal relationship between two persons or two parties, where one party has the right to demand something from another party, and the party is obliged to fulfill the demands. The party who demand something is called creditor or the claim owner, while the party who is obliged to meet a demand is called debtor or the indebted. ${ }^{6}$ The meaning of legal relationship in the sense of engagement is a relationship, which is consequently regulated by law. Therefore, it must be distinguished from relationships in the social life based on politeness, propriety, and decency.

An agreement must contain four terms of validity as regulated in Article 1320 of the Civil Code, a compelling provision. The first and the second terms concern the subject or parties in the agreement. Therefore, it is called subjective terms. The third and the fourth terms are called objective terms because it involves objects of agreement. In objective terms, if the terms are not met, the agreement is invalid, meaning that from the beginning there has never been an agreement and there has never been an engagement. In the subjective terms, if the conditions are not met, then the agreement may be canceled at any time. Therefore, the treaty that has been made remains valid and binding the parties, as long as it is not canceled (by a judge) at a request of one of the parties. ${ }^{7}$

The first term, they who bind themselves agree the agreement. It implies that the parties that make the agreement have agreed or have a suitability of the will or mutual consent of their own will. The parties should make the agreement without coercion, error, or fraud. The approval may be stated expressly or secretly. ${ }^{8}$ Agreement or approval can be understood as a meeting of reasons. "Agreement is a coming together of mind; a coming together in opinion or determination; the coming together in accord of two minds on a given proposition. The union or two more minds in a thing done or to be done, a mutual assent to do thing agreement is a broader term e.g. an agreement might lack an essential element of contract". ${ }^{9}$

Subekti, Hukum Perjanjian, Jakarta: Intermasa, 1998, p.1.

Subekti, Ibid., p.20.

Riduan Syahrani, Seluk Beluk dan Asas-Asas Hukum Perdata, Bandung: PT. Alumni, 2006, p. 205.

Catherine Tay Swee Kian, Tang See Chim, Contract Law: Layman's Guide, Singapore: Times Books International, 1993, p. 20. 
Agreement is the encounter of two or more reasons about something that can be done or will be done and as a mutual approval to perform something.

The second term is the ability to make engagement. It is a general requirement to be able to act legally. The term covers to be mature, healthy mind, and not prohibited by a legislation to do a particular deed. ${ }^{10}$ The third term cover certain things relating to achievement or object of agreement. Based on Article 1333 of the Civil Code, items that can be the object of agreement must be certain, at least must have been determined. If the amount is not specified, it is not an obstacle as long as the amount can then be determined or calculated. Article 1334 of the Civil Code also states that goods that will be appeared in the future may become object of agreement. The fourth term is a legal cause or causa, which means the purpose of an agreement. Article 1335 of the Civil Code states that an agreement without a cause, or which has been made for a false or forbidden cause, has no power. In addition, Article 1337 of the Civil Code is stipulated that a cause of agreement shall not be contrary to law, morality, and public order.

An agreement must be carried out in good faith (goede trouw), before, during, and after implementation of agreement. Good faith is a vital principle and holds a very important function in making an agreement. Good faith becomes part of a legal obligation, especially in its implementation. ${ }^{11}$ Article $1338(3)$ of the Civil Code mentions that "An agreement shall be done in good faith". The law provides no notion of good faith, so there is no clear definition. Good faith is an abstract understanding and it is difficult to formulate. However, it can be explained that parties must have a good faith as is proper between polite people, without trickery, deceit, damages, disturbing others. It should also not to be performed to generate one's own interests but also by generating interests of others. ${ }^{12}$ Execution of agreement must proceed with respect to norms of propriety and decency. It means that the implementation of agreement must run on right rails. Thus, a good faith indicates that the agreement is in accordance with propriety and justice. In other words, good faith means that the agreement is not contrary to propriety and justice.

The principle of good faith originally comes from Roman law. In Roman law, this principle is called Bonafides. The Civil Code uses the term good faith in two senses. First, good faith in a subjective sense. Good faith in a subjective sense is called honesty. Honesty does not lie physically. It lies in the actions taken by both parties in carrying out the agreement. Therefore, honesty is dynamic. Good faith in this subjective sense is an inner attitude or a state of the soul. The second sense of good faith in objective sense. In Indonesia, it is called propriety. Honesty in dynamic sense or propriety is rooted in the nature of the role of law in general.

Riduan Syahrani, Op.cit., p. 208.

Marilang, Perikatan Yang lahir dari Perjanjian, Makasar: Indonesia Prime, 2017, p. 151.

P.L. Wery, "Perkembangan Hukum tentang Itikad Baik di Nederland", this paper is presented for speech in Lustrum II of the Notariate Specialist Study at Airlangga University, Surabaya on 26 January 1990. 
$t$ is an effort to establish a balance of various interests that exist in society. ${ }^{13}$ $\mathrm{n}$ other words, good faith means inner states of parties in making and executing an agreement should be honest, open, and trusted. The inner states of parties should not be contaminated by intentions to deceive or cover up real situation.

In addition to the principle of good faith, certain important principles in agreement are the principle of consensualism. Consensualism means mutual agreement. This principle is contained in Article 1320 of the Civil Code. It is mentioned on the first condition of agreement validity that they, who bind themselves, are agreed. An agreement has been in effect since it reach mutual understanding between parties. For certain agreements, this principle cannot be applied -for example in a credit agreement where there is a provision requiring an underlying written agreement. Such agreement is a formal agreement. ${ }^{14}$ Likewise, sale and purchase agreement on land, besides mutual understanding, the agreement must be written in the form of deed made by the Land Titles Registrar.

The next principle is the principle of binding force. The principle determines that a legally-made contract will bind the parties concerned as law. The attachment of parties to an agreement is not limited only to the contracted points, but also to everything that is required by the propriety, custom, or law as set forth in Article 1339 of the Civil Code. The principle of binding force is contained in Article 1338(1) and (2) of the Civil Code as follows:

(1) Semua perjanjian yang dibuat secara sah berlaku sebagai undangundang bagi mereka yang membuatnya. [All legally-made agreements act as laws for those who make them]

(2) Perjanjian-perjanjian itu tidak dapat ditarik kembali selain dengan sepakat kedua belah pihak, atau karena alasan-alasan yang oleh undang-undang dinyatakan cukup untuk itu. [Agreements shall not be withdrawn other than by mutual agreement, or for reasons which the law expresses sufficient]

Under the terms, parties shall fulfill and respect what has been agreed in their agreement, binding as the law for them. This indicates legal certainty for the parties. The paragraph (2) mentions clearly that an agreement is irrevocable unless the parties agree to cancel the agreement, or for reasons which the law has regulated.

The next is the principle of freedom of contract. The principle states that each person, in principle, can make agreements with anyone, determine content of any agreement as long as it is not contrary to law, morality, and public order. The freedom to make such agreement enables someone to create individual rights that are not regulated in Book III of the Civil Code. The rights are stipulated in the agreement because the agreements act as laws for those

13 Inaugural Speech of Siti Ismijati Jenie as the Professor of the Faculty of Law, Gajah Mada University on 10 September 2007.

14 J. Satrio, Hukum Perikatan: Perikatan yang Lahir dari Perjanjian, Bandung: Citra Aditya Bakti, 1995, p. 50. 
who make them (Article 1338 Paragraph (1) of the Civil Code)..$^{15}$ Freedom of contract as the liberty or ability to enter into agreement with others. ${ }^{16}$ The principle of freedom of contract, under Indonesian law, includes ${ }^{17}$ : (1) a freedom to make or not to make an agreement; (2) a freedom to vote parties to be involved; a freedom to determine or to choose the causa of agreement; a freedom to determine objects of agreement; a freedom to determine the form of agreement; a freedom to accept or to deviate from optional provisions of law.

Understanding the principle of freedom of contract here is not in the sense of absolute freedom because there are various restrictions by law, public order, and morality. ${ }^{18}$ Freedom of contract always gives rise to the consequences that a contract to be made is always based on two unequal interests and leads to the same objectives. The principle of freedom of contract should be understood as a pattern of partnership in contract. It means that, in making agreement, parties should consider other parties to obtain results and benefits that are similar to themselves. ${ }^{19}$

\section{Credit Agreement as an Agreement between Bank and Debtor}

Based on the principle of freedom of contract, various kinds of unnamed agreements arise among the people. It shows that the agreements are not specifically regulated in the Civil Code -for example the law only regulates loan in general terms but in practice there is a type of agreement called credit agreement. Credit agreement is not a borrowing and lending agreement as referred to in Book III of the Civil Code. ${ }^{20}$ The credit agreement in banking practice is an unnamed agreement (onbenoemde overeenkomst). The legal basis for credit agreement apply the provisions under Article 1338(1) of the Civil Code, which are known as articles containing the principle of freedom of contract. The loan agreement between a bank and a debtor is based on the agreement between parties, namely the agreement of bank, as the creditor, and the debtor. ${ }^{21} \mathrm{An}$ unnamed agreement is an agreement that arise, grow, live, and thrive in society.

Credit Agreement is not specifically regulated in the Civil Code nor in the Banking Law. Therefore, the form of the credit agreement is not determined. The forms and materials of credit agreements made by banks are not similar. It occurs to adjust to the needs of each bank. Thus, credit agreement does not have a uniform and generally accepted form. However, any agreement, especially credit agreement, between bank and customer must pay attention to all aspects of contract law, in

\footnotetext{
Riduan Syahrani, Op.cit., p. 204.

16 Steven H. Gifis, Law Dictionary, New York: Barron's Educational Series, 2010, p. 212.

17 Sutan Remy Sjahdeiny, Kebebasan Berkontrak dan Perlindungan yang Seimbang Bagi Para Pihak Dalam Perjanjian Kredit Bank di Indonesia, Jakarta: Institut Bankir Indonesia, 1993, p. 47.

18 Subekti, Op.cit., p. 13.

19 H. Akh. Munif, "Kontrak Standard dalam Perjanjian Sewa Beli Rumah dan Akibat Hukumnya”, Jurnal Yustitia, Vol. 8, No. 1, 2008, p. 14.

20 Mariam Darus Badrulzaman, Kompilasi Hukum Perikatan, Bandung: PT. Citra Adtya Bakti, 2001, p. 25.

21 Djuhaendah Hasan, Lembaga Jaminan Kebendaan Bagi Tanah dan Benda lain yang Melekat pada Tanah dalam Konsepsi Penerapan Asas Pemisahan Horisontal, $2^{\text {nd }}$ printing, Jakarta: Nuansa Madani, 2011, p. 133.
} 
particular applying the principles of agreement and the terms of agreement. If a credit agreement does not comply with the principles of contract law and does not meet the validity requirements of an agreement, then the credit agreement can be canceled or declared null and void.

Article 1(11) of the Bankling Law generally defines credit as follows:

"Kredit adalah penyediaan uang atau tagihan yang dapat dipersamakan dengan itu, berdasarkan persetujuan atau kesepakatan pinjam meminjam antara bank dengan pihak lain yang mewajibkan pihak peminjam untuk melunasi utangnya setelah jangka waktu tertentu dengan pemberian bunga".

[Credit is the act of supplying money or equivalent claims based on a loan agreement or agreement between a bank and another party requiring the debtor to repay the debt after a certain period with interest]

These provisions clearly describe an achievement of money provision. It is based on mutual understanding or loan agreement between bank and debtor. There is an obligation of debtor to repay debt within a certain period. In other words, there should be payments in installments and debt repayment that is accompanied by interest.

The distribution of funds through credit to the people is an activity that plays a very important role in the life of banking business. ${ }^{22}$ Credit can be linked as a veins of banking, the source of life. Therefore, if the credit does not run well, it will create risk chances for a bank to be liquidated. Credit is bank's most important business activity, with the aim of generating profit as well as to help customers who need funds for the development and the expansion of their business. When the banks are able to channel more credits, there will be influential impacts. More entrepreneurs can develop and create job opportunities for the people, which led to the economic development in various sectors.

The distribution of credit to debtor is performed based on a confidence, after a thorough analysis, with consideration of some matters to the good faith, the ability, and capability of the debtor to repay the debt and the interest in accordance to an agreement. Referring to Article 8 and the explanation of the Banking Law, bank in releasing its credit shall pay attention to the principles of good credit. Prudential Banking Principle in credit distribution is implemented after a thorough assessment of various aspects of the prospective debtor. This is known as the 5Cs Analysis of Credit (Character, Capacity, Capital, Condition of economic, Collateral). Bank, prior to crediting, should undertake a careful assessment of nature, capability, capital, collateral, business prospect funds of debtor.

22 Tarsisius Murwadji dan Achmad Hagi Robby, “Edukasi dan Penyehatan Koperasi Melalui Linkage Program Perbankan" Padjadjaran Jurnal IImu Hukum (PJIH), Vol. 4, No. 3, Year 2017, p. 465. 
Bank places or distributes funds to debtors based on trust. Bank believes that debtors will not abuse the trust, will manage loan fund properly, will have ability to pay at maturity, and has good intention to return the loan along with other obligations at maturity. ${ }^{23}$ Distribution of bank funds is based on the belief in the ability of debtor to return the loan on time in accordance with agreement.

Credit agreement contains rights and obligations of each party which will be the law for all parties. The agreement is generally made in a fixed form. The contents have been unilaterally determined by bank. If the debtor agrees on the contents of the credit agreement and sign it, then there is an agreement and the contents bind both the bank and debtor. Whenever there is a violation on the agreement, the bank can take action based on clauses that have been agreed.

\section{Bad Debt as Risk for Bank}

Distributing credit means that bank gives trust to debtor even though the trust contains a high risk. In practice, credit provided by bank is not entirely refundable by some debtors on maturity. This can lead to problems, which eventually becomes bad debt.

Bad debt is a situation where a debtor cannot afford to pay off bank credit on maturity. ${ }^{24}$ The Civil Code defines the situations as default or broken promises. Bad debt are credits with non-performing loans, unpaid principal installment and interest for more than two installments plus twenty-one months, or the settlement of credit has been submitted to the court or State Receivables Agency, or has been submitted to the Credit Insurance Company. ${ }^{25}$ Bank will bear the losses on loans already granted and non-recoverable. There are arrears of principal installments and or interest that have exceeded the time already agreed.

The classification of credit according to the provisions of Bank Indonesia Decree Number 31/147/KEP/DIR and Circular Number 31/10/UPPB on the Asset Quality Rating for Commercial Banks, divides bank loans into five categories: current credit, in specific concern credit, less current credit, doubtful credit and bad credit. The provision of credit classification can be seen in the Regulation of Bank Indonesia Number 11/2/PBI/2009 on the Third Amendment of the Regulation of Bank Indonesia Number 7/2/PBI/2005 on the Asset Quality Rating for Commercial Banks. According to the Regulation of Bank Indonesia, the classification of credit is based on assessment factors. They are business prospects, performance of debtor, and ability to pay.

Based on the assessment of credit quality, the current credit category is defined as a credit that is smooth or satisfactorily. It covers no arrears of interest or principal installments; the loan is not on maturity; customer settles all obligations properly;

\footnotetext{
Sigit Triandaru dan Totok Budisantoso, Bank dan Lembaga Keuangan lain, Jakarta: Salemba Empat, 2006, p. 9. Gatot Supramono, Perbankan dan Masalah Kredit Suatu Tinjauan Yuridis, Jakarta: Rineka Cipta, 2009, p. 131. Hasanuddin Rahman, Aspek-aspek Hukum Pemberian Kredit Perbankan di Indonesia, Revised Edition, Bandung: Citra Aditya Bakti, 1998. p. 128.
} 
the payment is on time; good account development; and no arrears in accordance with credit terms. In specific concern credit indicates a weakness in financial condition or creditworthiness of debtor. It covers a credit with noncurrent mutation for 1-2 months; debtor began to delinquent installment of principal and/or interest; there are arrears of principal and/or interest payments up to ninety days.

Less current credit are credit with noncurrent mutation for 3 or 6 months, not good payments of interest or principal installments due to a very unfavorable change in terms of debtor financial and management or economic or political in general; indications of financial problems of debtor; bank approaches have been made but the results are not good; there are arrears of principal and/or interest payments that have exceeded 90 (ninety) days up to 120 (one hundred and twenty) days. Doubtful credit is credit that is not smooth and has matured; cannot be completed by the debtor concerned; is in doubt; and potentially causing losses to the bank. There are principal and/or interest arrears, which have gone beyond 120 (one hundred and twenty) days up to 180 (one hundred and eighty) days.

The last, bad credit, is the last phase of failed settlement or reactivation of noncurrent credit. A credit is categorized into bad credit after bank have already taken all steps required to settle but failed. The credit has been assured to be non-recoverable. Bank will bear the losses on the credits, and there are outstanding principal and/or interest arrears, which have exceeded 180 (one hundred and eighty) days.

Bad debt and nonperforming loans are different. Bad debt is a loan problem but not all of loan problems are bad credit. Credits that are classified as current, in specific concern, and less current are called loan problems. Nonperforming loans are credits that have not yet reached or met the desired target of bank. The debtor usually faces difficulties in settling obligations, either payments of principal and/or interests, fine, and charges. Debtors whose have active businesses, despite stagnant, weak ability to pay installment, can still recover nonperforming loans and pay interests. Debtors whose have inactive businesses can still be helped, if the credit guarantee ratio is still sufficient and there are other businesses that are considered productive. The debtor can be given a new fund injection so that the results can be used to pay all obligations. All such efforts are called rescued loans through negotiations between debtor and bank, which is, of course, followed by a new credit agreement either in the form of innovation, subcontracting, compensation, or in simply an addendum to the credit agreement.

There are several forms of credit rescue. Bank can make rescheduling. The bank changes credit terms related to payment schedule. This policy is related to the term of credit so that the relief that can be given is to extend credit term, installment period, and reduce for each installment. Another way, bank can make reconditioning or re-requirement. It is a partial or completely changes of credit terms that are not limited to schedule, duration, and other requirements. Bank can provide interest relief or changes to the terms of loan, among others, with interest capitalization, 
interest payment delay, interest rate decline, and even temporary or permanent interest exemption for all interest payables and short-term credit conversion into long-term on easier terms. The subsequent form of credit rescue is by restructuring or reordering. It is changes in credit terms involving additional bank funds. Some interest arrears are converted into the principal and the conversion of all or part of credit to equity participation in the company. Measures that can be taken in the framework of restructuring are additional credit and additional equity. ${ }^{26}$

Bad credit is a credit that cannot be recovered anymore. The only settlement is made by executing object of guarantee. The occurrence of bad debt and loss can be caused by several factors as follows: ${ }^{27}$

1. Bad faith of customers;

2. Customer's own fault;

3. Changes in legislations and laws;

4. General economic conditions and situations;

5. Force majeure;

6. Careless bank.

In addition, debtor may be unable or not master the field of business financed by credit, or the debtor cannot manage business properly. Many family problems or personal problems of shareholders of debtors' corporate clients can destroy the company's business operations. The risk of bad debt can be even greater in the family business entity in which one or more members of the family owned a company. Some examples of family problems or personal problems that can lead to the emergence of problem loans are divorce, new marriage, death, extravagance, prolonged illness, and mental depression.

Generally, in addition to external problems, bad debts in credit agreements are also problems that come from banks and debtors. Bad debt that are caused by debtor covers the moral hazard of some debtor, either debtors with large credit and small credit. The lack of good faith of debtor, among others, covers fictitious credit, deviating from the bank's credit distribution. The debtor does not use any credit earned in accordance with its purpose, so that the use of a deviant credit will result in the failure of debtor. It also covers the fraud by making the maximum profit for own interest. Debtor deliberately with all efforts get credit. However, but the credit is obtained, it is used for interests that cannot be accounted. In some cases, debtors have already run away before the maturity of credit.

\section{E. Prudential Banking Principles in Credit Distribution}

Bank actually has good intentions by giving credit to debtors based on loan application from the debtors. However, some debtors who have bad faith often misuse bank's trust. The debtors, from the beginning, do not have an intention to return the credit, even with various risks. In this case, bank is also less careful in assessing the character

26 Hermansyah, Hukum Perbankan Nasional, $2^{\text {nd }}$ edition, Jakarta: Prenada Media Group, 2014, p.76.

27 Gatot Supramono, Op.cit, p. 21. 
or the nature of potential debtors. The character or personality of debtors is an important element in the provision of credit. The character in this principle covers a good faith of the prospective debtor, i.e. those who always keep their promises and try to prevent disgraceful acts. The good faith of someone make the person to be honest, morally trustworthy and able to perform obligations.

The source of credit funds is mostly not from the bank itself, but from the community. The public entrusts the funds deposited in the bank through savings, time deposits, demand deposits, certificates of deposit certificates, and or other similar forms. Therefore, bank must be responsible to any credit distribution. Bank, in preventing the occurrence of bad debts, in general and in particular due to bad debtor who is not good, applies the prudential banking principles. The obligation to apply prudential banking principles, especially in loans refers to the provisions of Article 8(1) of the Banking Law.

"Dalam memberikan kredit atau pembiayaan berdasarkan Prinsip Syariah, Bank Umum wajib mempunyai keyakinan berdasarkan analisis yang mendalam atau itikad dan kemampuan serta kesanggupan nasabah debitur untuk melunasi utangnya atau mengembalikan pembiayaan dimaksud sesuai dengan yang diperjanjikan".

[In granting credit or financing based on Sharia Principles, Commercial Banks shall have confidence based on in-depth analysis or the willingness and ability and capability of debtors to settle their debts or to refund the financing in accordance with the agreement]

Furthermore, the Explanation of Article 8(1) explains as follows:

"Kredit atau pembiayaan berdasarkan Prinsip Syariah yang diberikan oleh bank mengandung risiko, sehingga dalam pelaksanaannya bank harus memperhatikan asas-asas perkreditan atau pembiayaan berdasarkan Prinsip Syariah yang sehat. Untuk mengurangi risiko tersebut, jaminan pemberian kredit atau pembiayaan berdasarkan Prinsip Syariah dalam arti keyakinan atas kemampuan dan kesanggupan Nasabah debitur untuk melunasi kewajibannya sesuai dengan yang diperjanjikan merupakan faktor penting yang harus diperhatikan oleh bank. Untuk memperoleh keyakinan tersebut, sebelum memberikan kredit, bank harus melakukan penilaian yang seksama terhadap watak, kemampuan, modal, agunan, dana prospek usaha dari Nasabah debitur..."

[Credit or financing based on the Sharia Principles provided by banks contains a risk, so in the practice, the bank must pay attention to the principles of crediting or financing based on correct Sharia Principles. To mitigate such risks, credit or financing assurance based on Sharia Principles in the sense of confidence in the ability and capability of debtors to settle their obligations as agreed is an important factor that 
must be considered by bank. To obtain such confidence, before giving credit, bank must perform careful assessment of character, capability, capital, collateral, business prospect fund of debtor..." ]

As Article 8 of the Banking Law states that prior to granting credit, the bank must carry out a thorough assessment. Therefore, it is necessary to apply the Prudential Banking Principles through an accurate and in-depth analysis, the proper distribution of targets, and fulfilling legal requirements, binding the formal legal guarantees based on legal and regulatory provisions concerning good warranties, supervision and monitoring, valid agreements and regular and complete credit documentation. All of them are aimed to enable the credit to be fulfilled in accordance with the credit agreement covering principal and interest.

In giving credit, bank must follow appropriate stages to avoid problems. Before a credit facility is given, prior to the credit agreement is approved, bank should be assured that the credit will be actually returned. The confidence is derived from the results of a thorough assessment of the prospective debtor before the credit is distributed. Credit rating can be done in various ways to gain confidence on debtor such as through proper, meticulous, thorough, and prudent procedures by minimizing the possibility of risks. In the implementation, bank should pay attention to the principles of good credit. Banks should apply prudential banking principle, to prevent and to reduce the occurrence of these risks.

On the basis of the provision of a good credit, each bank is required to carry out an assessment that cover various aspects. The prudential by the principle of $5 \mathrm{Cs}$ is implemented. Based on the explanation on Article 8 of the Banking Law, when a bank conduct analysis towards prospective debtors, it must be done thoroughly on character, ability, capital, collateral, and business prospects of the debtor.

Assessment of good character who is honest and able to cultivate a company can be seen from management abilities, whether he/she is able to produce well is seen from his/her production capacity. The assessment of someone's capacity is based on experience in business world attributed to education as well as company strength and adaptability to technological developments. Capital and financial ability of debtor has direct correlation with the level of ability to pay. To overcome risks that may arise on debtor's failure to pay, the existence of collateral or collateral is required. Bank needs to pay attention about the business of prospective debtors. The availability of guarantee is one of the factors in determining the status of the credit. The definition of guarantee here is a special guarantee, not a guarantee in general abstract meaning. For example, the guarantee is in the form of material and personal (borghtocht). ${ }^{28}$ Material guarantee gives more assurance of debt repayment from defaulted debtor.

The bank credit contains many risks. Therefore, in its implementation, in addition to conduct 5Cs analysis as an implementation of the prudential principle

28 Etty Mulyati, Kredit Perbankan Aspek Hukum dan Pengembangan Usaha Mikro Kecil dalam Pembangunan Perekonomian Indonesia, Bandung: PT Refika Aditama, 2016, p. 85. 
externally, the bank must apply Risk Management internally. Risk Management is arranged through the Regulation of the Financial Services Authority Number 18 /POJK.03/2016 on the Implementation of Risk Management for Commercial Banks. The purpose of this arrangement is to control the risks faced by bank. The Regulation of Bank Indonesia about Risk Management mentions "Risk Management is a set of procedures and methodologies to identify, quantify, monitor, and control risks arising from bank operations". Risk can be defined as the potential occurrence of an event that can cause bank losses.

In the business world, risk will always exist. There is no business that has no risk, so at all times risk should be minimized. Risk is not to be avoided but it is to be dealt with in ways that minimize the likelihood of a loss. Risk may arise at any time, so that the risk does not preclude business activities of bank. Then, risk must be managed properly. If risk that exists or arises can be managed, known, and understood by bank's management to create a solution optimally. Increased risk must be balanced with adequate risk control. To control risk, bank needs to improve the quality of risk management implementation.

There are eight risk categories, which are related to credit. One of them is credit risk. Based on the Regulation of Financial Service Authority about Risk Management, Credit Risk is the Risk due to the failure of other parties in fulfilling obligation to Bank, including Credit Risk due to debtor's failure, credit concentration risk, counterparty credit risk, and settlement risk. It also covers debtor's failure to implement credit agreement, so that the debtor cannot fulfill obligation to Bank at maturity. For most banks, loan is the source of the greatest credit risk. The level of credit risk is influenced by several factors, such as the concentration of credit. Credit risk may increase due to the concentration of funding. Credit concentration risk is a risk arising from the concentration of funds to single party or group of industries, sectors, and/or geographic areas that potentially cause significant losses that can threaten the bank's continuity. Counterparty credit risk is a risk arising from the failure of the counterpart in fulfilling obligations and arising from the type of transaction that has certain characteristics, such as transactions that are affected by the movement of fair value or market value. Settlement risk is a risk arising from the failure to deliver cash and/or financial instruments on the agreed settlement date of the transactions of sale and/or purchase of financial instruments. Operational Risk is a risk due to inadequacy and/or malfunction of internal processes, human error, system failure, and/or the presence of external events affecting bank operations, malfunctioning internal processes, as well as human error or deception, system failure to record and to report a complete, correct, and timely manner transactions. Then, Compliance Risk is a result of the bank does not obey or not enforce the applicable laws and regulations. Compliance risk management is done through consistent implementation of internal control system. Legal risks arise, among others, due to the absence of legislations that supports or the weaknesses of engagement 
such as non-fulfillment of the conditions of validity of the contract or the binding of imperfect guarantee. Legal risk is caused by lawsuit or weakness of juridical aspect. That is less attention to adequate legal requirements in order to protect bank.

Efforts to prevent and to reduce risk of bad debts is a form of risk management implementation intended to enable banks to measure and to control risks that may occur in conducting business activities. Therefore, banks can maintain their health level. Bank is expected to be able to carry out all of its activities in an integrated, accurate, and comprehensive risk management system.

\section{F. Bank's Anticipation of a Bad-Faith Debtor}

In the practice of credit, banks often face debtors with bad faith, which then cause credit problems and eventually become bad credit. A debtor with bad faith is debtor or insurer or debt guarantor that is actually capable but does not fulfill obligation to repay debts. Some debtors deny its obligation to repay principal and interest as agreed in credit agreement. Bank, in anticipating the occurrence of nonperforming loans from bad debtor, before credit application is approved, shall conduct an indepth analysis on the assessment of debtor. The analysis should cover character, capability, capital, collateral, and business prospects as mandated by Article 8 of Banking Law.

Credit assessment is to prevent bad credit, assuring that the credit will not cause a problem. Bank should consider willingness and ability of debtor to pay credit. To know willingness and ability of debtor, bank conducts $5 \mathrm{Cs}$ analysis on Character, Capacity, Capital, Collateral, and Condition, so the bank can have confidence that the credit that will be returned on maturity. Credit analysis should be done in such a careful way. It is difficult to give an assessment to assure bank's confidence. in this case, the element to be the focus of assessment should be clear. Confidence alone does not contain legal aspects that will be the guidance for the bank, that the money that has been channeled will be returned at maturity.

Character assessment is an important factor to know personality, nature, character and honesty of debtor in fulfilling obligations, such as promises and willingness to pay credit on time. A well-characterized debtor possesses positive and cooperative morale, character, and personal qualities, responsible in personal life as a member of society and in carrying out business activities. In addition, as a supporting information in credit decision, in order to avoid the future of nonperforming loan, bank can assess credit reputation of prospective debtors through the Debtor Information System (SID -Sistem Informasi Debitur). SID is a system that provides information in the form of data of debtor, owner, and management. It also provides information on facility of funds received by debtor, collateral, guarantor, and collectability. Along with the transfer of bank supervision from Bank Indonesia to the Financial Services Authority, started from January 1, 2018, the SID managed by Bank Indonesia has been replaced with Financial Services Authority-managed Financial Information Service System (SLIK -Sistem Layanan 
Informasi Keuangan). The existence of SLIK is to find out banking credit data such as debtor's principal data, credit limit, debit balance, credit quality, interest expense, payment installment as well as loan penalty. Thus, if a prospective debtor has loans in other banks or financial institutions, bank will have prior information and its reputations.

In addition to the potential debtor's character, the assessment point in securing the credit is on the collateral, in which case the guarantee specifically promised in the form of the debtor's property guarantee. The binding should be in accordance with provisions of legislations governing guarantee. The binding of guarantee must fulfill the juridical requirement that the object must actually belong to the debtor, and be in its power, not being disputed with a third party, having valid and trusted proof of ownership on behalf of debtor, and the proof of ownership is eligible for binding on mortgages, pledges, fiduciary, and loans. Economic conditions also must be met. The guaranteed object should have economic value, marketable, the value is constant, the condition and location is strategic, and the value of the guarantee object must be greater than the amount of credit granted. For the sake of credit safety both conditions must be met, but if the juridical and economic conditions are perfectly difficult, then it is better juridical conditions must be met in order to avoid experience difficulties during execution.

The object of guarantee is the most powerful tool in overcoming bad credit because it will provide the right and power to bank to get debt repayment from debtor. Repayment is obtained from auction of guaranteed goods. This will minimize the risk of loss that may arise if debtor is unable and does not want to repay debt on maturity as specified in credit agreement.

After credit is disbursed, bank routinely monitors credit developments of debtor to detect the symptoms of nonperforming loans. Therefore, they can make an early decision on what should be done to save funds from the debtor. The symptoms cover, among others, the deviation from the terms of credit agreement, requesting to extend credit term that will mature without giving a strong reason, late payment of mature principal and interest. Bank shall continue to thoroughly examine debtor's financial statements, as debtor's may conceal his financial difficulties by submitting a pre-engineered financial report. The untruth of information can be seen from the development of the ongoing credit. The good relationship between debtor and bank has an important role in the bank's success to monitor credit development. If there is a decrease in cooperative attitude of debtor, bank will have difficulty in performing its duties since the debtor does not convey financial information required by the bank.

Banks regularly monitor the object of collateral available to the debtor because there can be other problems. The object of the collateral is bound by fiduciary guarantee, the possession of the collateral object is in the debtor, and the bank holds only the proof of ownership document. If the debtor is not good enough, often the value of the collateral becomes lower so that the value is less than the amount of credit balance. In some cases, debtor switched or transferred guaranteed 
objects, re-pledged to third parties, or even sold without the knowledge of bank. In addition, if a family problem or a personal problem of the debtor arises, bank must constantly monitor its credit development so that it can take action to save credit funds whenever the bank feels that there is a problem that potentially can be bad credit and dangerous.

If all attempts have been made to save the credit, but at the end there is still a bad credit, the settlement is to execute the guaranteed object that has been tied perfectly in accordance with the provisions of the legislations on the guarantee, whether mortgage, pledge, fiduciary, or burden.

\section{G. Conclusion}

The implementation of prudential principles by applying the correct credit provision, on the establishment and implementation of credit agreements between banks and debtors, is needed to prevent bad debts. Before a credit is given, prior to the credit agreement is approved, bank must be assured that the credit will actually return. This confidence is derived from the result of a thorough analysis of the character, capability, capital, collateral, and business prospects of debtor, as the implementation of the prudential principle -known as the 5 Cs principle.

The availability of guarantees is one of the factors in determining whether or not a credit is distributed, with formal legal guarantees in accordance with the laws and legislations. Credit provided by bank contains many risks, so in its implementation, in addition to conducting $5 \mathrm{Cs}$ analysis, as an implementation of prudential principles, bank must apply risk management internally. It is to measure and to control risk that may occur in business activities. After the credit is given, the bank must monitor the development of credit so that it can detect the symptoms of nonperforming loans. Thus, bank can take action to save the funds that have been channeled. In the event of a credit default, the settlement is by executing collateral object that has been completely bound. The execution should be in accordance with the laws.

\section{References}

Books

Busch, Andreas, Banking Regulation and Globalization, Oxford University Press Inc, New York, 2009.

Djuhaendah Hasan, Lembaga Jaminan Kebendaan Bagi Tanah dan Benda lain yang Melekat pada Tanah dalam Konsepsi Penerapan Asas Pemisahan Horisontal, $2^{\text {nd }}$ printing, Nuansa Madani, Jakarta, 2011.

Etty Mulyati, Kredit Perbankan Aspek Hukum dan Pengembangan Usaha Mikro Kecil dalam Pembangunan Perekonomian Indonesia, PT Refika Aditama, Bandung, 2016.

Gatot Supramono, Perbankan dan Masalah Kredit Suatu Tinjauan Yuridis, Rineka Cipta, Jakarta, 2009.

Gifis, Steven. H., Law Dictionary, Barron's Educational Series, New York, 2010. 
Hasanuddin Rahman, Aspek-aspek Hukum Pemberian Kredit Perbankan di Indonesia, revised edition, Citra Aditya Bakti, Bandung, 1998.

Hermansyah, Hukum Perbankan Nasional, $2^{\text {nd }}$ edition, Prenada Media Group, Jakarta, 2014.

J. Satrio, Hukum Perikatan-Perikatan Yang Lahir dari Perjanjian, Citra Aditya Bakti, Jakarta, 1995.

Kasmir, Dasar-dasar Perbankan, Raja Grafindo Persada, Jakarta, 2002.

Kian, Catherine Tay Swee and Tang See Chim, Contract Law: Layman's Guide, Times Books International, Singapore, 1993.

Mariam Darus Badrulzaman, Kompilasi Hukum Perikatan, PT. Citra Adtya Bakti, Bandung, 2001.

Marilang, Perikatan Yang lahir dari Perjanjian, Indonesia Prime, Makassar, 2017.

Muhamad Djumhana, Hukum Perbankan di Indonesia, PT. Citra Aditya Bakti, Bandung, 2000.

Riduan Syahrani, Seluk Beluk dan Asas-Asas Hukum Perdata, PT. Alumni, Bandung, 2006.

Sigit Triandaru dan Totok Budisantoso, Bank dan Lembaga Keuangan lain, Salemba Empat, Jakarta, 2006.

Subekti, Hukum Perjanjian, Intermasa, Jakarta, 1998.

Sutan Remy Sjahdeiny, Kebebasan Berkontrak dan Perlindungan yang Seimbang Bagi Para Pihak Dalam Perjanjian Kredit Bank di Indonesia, Institut Bankir Indonesia, Jakarta, 1993.

Thomas Suyatno, Dasar-dasar Perkreditan, PT. Gramedia Pustaka Utama, Jakarta, 2003.

\section{Other Documents}

Abu Hanifa Md. Noman, "The Effect of Credit Risk on the Banking Profitability: A Caseon Bangladesh", Global Journal of Management and Business Research (C) Finance, Vol. 15, Issue 3, 2015.

H. Akh. Munif, "Kontrak Standar dalam Perjanjian Sewa Beli Rumah dan Akibat Hukumnya", Jurnal Yustitia, Vol. 8, No. 1, 2008.

P. L. Wery, "Perkembangan Hukum tentang Itikad Baik di Nederland", this paper is presented for speech in Lustrum II of the Notariate Specialist Study, Airlangga University, Surabaya on January 26, 1990.

Tarsisius Murwadji and Achmad Hagi Robby, "Edukasi dan Penyehatan Koperasi Melalui Linkage Program Perbankan" Padjadjaran Jurnal Ilmu Hukum (PJIH), Vol. 4, No. 3, 2017.

\section{Law Documents}

Indonesian Code of Civil Law.

Law Number 7 of 1992 on the Amendment of Law Number 10 of 1998 on the Banking. 
Regulation of Bank Indonesia Number 11/2/PBI/2009 on the Third Amendment of the Regulation of Bank Indonesia Number 7/2/PBI/2005 on the Asset Quality Rating for Commercial Banks.

Regulation of the Financial Services Authority Number 18 /POJK.03/2016 on the Implementation of Risk Management for Commercial Banks.

Decree of Bank Indonesia Number 31/147/KEP/DIR and Circular of Bank Indonesia Number 31/10/UPPB on the Asset Quality Rating for Commercial Banks. 